\title{
The Analysis of Inpatients Satisfaction on Service Quality At Yogyakarta Respira Hospital
}

Dahyanto*, Fitri Arofiati**

*Correspondent Author: h.dahyanto@gmail.com

*Master of Hospital Management, Postgraduate in Universitas Muhammadiyah Yogyakarta, Indonesia

**Master of Nursing, Postgraduate Program, Universitas Muhammadyah Yogyakarta, Indonesia

\begin{tabular}{l}
\hline I N D E X I N G \\
\hline Keywords: \\
Patient Satisfaction; \\
Service Quality; \\
COPD;
\end{tabular}

Kata Kunci:

Kepuasan Pasien;

Mutu Pelayanan;

PPOK;

\begin{abstract}
A B S T RAC T
Health service quality is the level of perfection of health services that are organized in accordance with the code of ethics and service standards, so as to give satisfaction for each patient. This study aims to analyze the satisfaction of inpatients in the disease section at Respira Yogyakarta Hospital. Method: Mix-method research with a case study design. The quantitative samples are questionnaires (March - April 2017, n =9). And the qualitative samples are lung specialists, nurses, nutritionists and people who are involved in patient satisfaction $(n=30)$ taken using purposive sampling technique. Results: Input: Inpatients at RS Respira Yogyakarta are satisfied. This hospital plays a role in the quality of health services. One of its ways is to provide the amount of equipment in Inpatient Installation according to the needs of patients, both in terms of its quality and quantity. Process: Development of patient satisfaction has involved the health service quality team. Obstacles are still in the way in fulfilling patient satisfaction including non-routine satisfaction surveys, uneven knowledge, lack of ownership, low of professionalism, evaluation of patient satisfaction is not done routinely. Output: Patients feel satisfied with the service at Respira Yogyakarta Hospital. Conclusions: The result of this research is that inpatients at Respira Yogyakarta Hospital are satisfied.

Mutu pelayanan kesehatan merupakan tingkat kesempurnaan pelayanan kesehatan yang diselenggarakan sesuai dengan kode etik dan standar pelayanan yang ditetapkan, sehingga menimbulkan kepuasan bagi setiap pasien. Tujuan penelitian ini yaitu untuk mengetahui kepuasan pasien di RS Respira Yogyakarta. Penelitian mix method dengan desain studi kasus. Sampel kuantitatif adalah kuesioner (Maret - April 2017, n=9). Sampel kualitatif adalah dokter spesialis paru, perawat, ahli gizi dan orang-orang yang terlibat dalam pemenuhan kepuasan pasien $(n=30)$ dengan teknik quote sampling. Input: Terdapat Kepuasan pasien Rawat Inap di Rumah Sakit Respira Yogyakarta, Rumah Sakit Respira Yogyakarta ikut berperan dalam mutu pelayanan kesehatan, Jumlah peralatan di Instalasi RawatInap Yogyakarta sesuai dengan kebutuhan pasien, baik secara kualitas maupun kuantitas. Proses: Pengembangan kepuasan pasien telah melibatkan Tim mutu pelayanan kesehatan, Masih terdapat hambatan dalam pemenuhan kepuasan pasien diantaranya yaitu Survey kepuasan tidak rutin, Pengetahuan yang tidak merata, Kurangnya ownership, Kurangnya attitude, evaluasi kepuasan pasien tidak dilakukan secara rutin, Aspek Output: pasien merasa puas terhadap pelayanan di Rumah Sakit RespiraYogyakarta. Kesimpulan: kesimulan dari penelitian ini adalah terdapat kepuasan pada pasien di RS Respira Yogyakarta
\end{abstract}

(C) 2018 JMMR. All rights reserved

Article History: Received 2017-Feb-5; Revised 2017-Sep-15; Accepted 2017-Okt-25

\section{INTRODUCTION}

Quality health services are services that are oriented to the satisfaction of each health service user based on the average level of satisfaction of service users. Satisfaction is a situation where the needs, desires and expectations of customers can be fulfilled through the products provided. Satisfaction is related to the recovery of patients from illness or injury. This is more related to the consequences of the nature of the health service itself, as well as the goals and outcomes of services. Patient satisfaction in assessing quality or good service is an important measurement that is fundamental to service quality. This is because it provides information on the success of quality service providers with the values and expectations of patients who have their own authority to set the desired quality of service standards. ${ }^{1}$

Patients are sick people who are treated by doctors and other health workers in practice. ${ }^{2}$ Meanwhile, satisfaction is a person's feeling of pleasure originating from the comparison between pleasure to activity and a product with his expectations. ${ }^{3}$ Customer satisfaction is the result (outcome) that is felt for the use of products and services, either fulfilling or exceeding the desired expectations. $^{4}$ 
Chronic Obstructive Pulmonary Disease (COPD) is a term frequently used for a group of pulmonary diseases that last for a long time and is characterized by an increase in resistance to air flow as a depiction of its main pathophysiology. ${ }^{5}$ COPD is a chronic pulmonary disease characterized by an obstacle to air flow in the airways that is non-reversibly progressive or partially reversible, as well as an inflammatory lung response to harmful particles or gases.

Patient satisfaction is the level of patient feelings that arise as a result of the performance of health services they receive, after the patient compares with what is expected. Patient satisfaction is something important, without satisfaction to goods and services then organizational expectations to continue to grow and survive will be very difficult to materialize. ${ }^{6}$

The customer satisfaction research gap refers to the McDougall and Levesquel's studies which have so far been debated in research on patient satisfaction. This research gap is important. In the absence of satisfaction to goods and services, the organization's expectation to continue to grow and survive will be very difficult to materialize. The quality of health services is the level of perfection of health services that is organized in accordance with the code of ethics and defined service standards, so as to generate satisfaction for each patient. ${ }^{7}$ Quality service is very necessary because it is the right of every customer, and can provide an opportunity to win competition with other healthcare providers. Service quality and value have a direct impact on customers. Quality service is very necessary because it is the right of every customer, and can provide opportunities for winning the competition with other healthcare providers. Service quality and value have a direct impact on customers. Respira Yogyakarta Hospital. There are 10 major hospitalizations in the hospital and its most number of patientsare those patients with COPD, as many as 117 patients, and most of them are elderly patients. Based on the foregoing, the researcher is interested in further researching the factors of patient satisfaction with the quality of medical services at Respira Yogyakarta Hospital.

\section{RESEARCH METHOD}

This is a mix-method study, employing both qualitative and quantitative methods. The qualitative method is its design of a case study in the inpatient unit of pulmonary disease in Respira Hospital Yogyakarta. The quantitative data are obtained by observation. The samples are taken from a population and using a questionnaire as a research instrument. Furthermore, the results of the previous questionnaire data are analyzed. This aims to determine the factors of patient satisfaction with the quality of service at the hospital, especially the services for pulmonary inpatients of Yogyakarta Respira Hospital.

In this study the subjects used are 2 nurses on duty in the ward, 1 ward head, 1 nutritionist, and the hospital director.

According to Supranto, the object of research is the set of elements that can be in the form of people. Also, the organization reveals that the object of research is the subject matter to be studied in order to get more directed data. ${ }^{8}$ Then the object in this study is the questionnaire data for inpatients at Respira Yogyakarta Hospital. This research will be carried out by Yogyakarta Special Lung Respira Hospital at Panembahan Senopati Street No. 4 Palbapang Bantul.

The quantitative analysis is performed using descriptive analysis of observations to determine the factors of patient satisfaction with the quality of service at the special hospital for pulmonary diseases, Yogyakarta Respira Hospital.

In terms of its qualitative analysis, the results of the questionnaire on the level of pulmonary-specific inpatient satisfaction are examined by the researchers and adjusted to the actual situation and conditions by conducting in-depth interviews to clarify the level of satisfaction of pulmonary inpatients. This is done by analyzing it qualitatively, i.e. byperforming analysis to get the actual data and it is carried out continuously during the research period. The data are then presented in narrative form, reduction, coding, and so on. The conclusions of the research results are determined by comparing the research questions with the results of the study.

\section{RESULT AND DISCUSSION}

\section{Results of Satisfaction of Inpatients at Respira Yogyakarta Hospital}

In this study a questionnaire is distributed to several respondents at the Respira Yogyakarta Hospital Inpatient Installation and the following results are obtained 


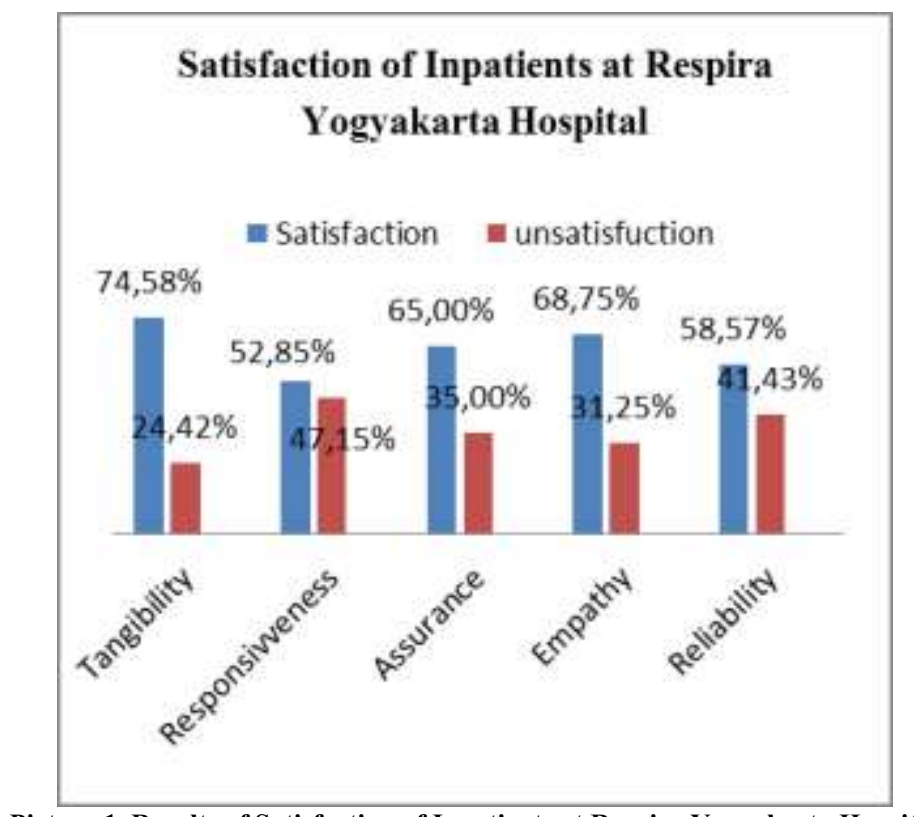

Picture 1. Results of Satisfaction of Inpatients at Respira Yogyakarta Hospital

From the results of the study, it is found that the dimension of tangibility in the level of satisfaction is $74.58 \%$ satisfied, $25.42 \%$ dissatisfied. The next dimension is responsiveness dimension, with its satisfaction level being $52.85 \%$ satisfied and $47.15 \%$ dissatisfied. Furthermore, the assurance of satisfaction level is $65 \%$ satisfied, $35 \%$ dissatisfied, then in the fourth dimension the satisfaction level is $68.75 \%$ satisfied, and $31.25 \%$ is dissatisfied. The last dimension is the reliability dimension, and the level of satisfaction is $56.57 \%$ satisfied, $41.43 \%$ dissatisfied.

\section{Description of Respondents}

Table .1 Description of respondents by Gender

\begin{tabular}{|c|c|c|c|c|c|c|}
\hline \multirow[t]{3}{*}{ Gender } & \multicolumn{4}{|c|}{ Patients Satisfaction } & \multicolumn{2}{|c|}{ Total } \\
\hline & \multicolumn{2}{|c|}{ Satisfied } & \multicolumn{2}{|c|}{ Unsatisfied } & \multirow[b]{2}{*}{$\mathrm{n}$} & \multirow[b]{2}{*}{$\%$} \\
\hline & $\mathrm{n}$ & $\%$ & $\mathrm{n}$ & $\%$ & & \\
\hline Female & 8 & 26.7 & 4 & 13,3 & 12 & 40 \\
\hline Male & 12 & $40 \%$ & 6 & 20 & 18 & 60 \\
\hline Total & 20 & $66.7 \%$ & 10 & 33,3 & 30 & 100 \\
\hline
\end{tabular}

Based on the table above, it can be seen that the male inpatients of Respira Yogyakarta is predominantly satisfied by $40 \%$. Gender has an influence on the views on to the services provided. Women see more in detail, while men do not heed it. How to manage relationships for men, they tend to be more indifferent to the things expressed by women, therefore they are considered more flexible than women. In terms of gender. ${ }^{9}$ According to Trisnantoro, gender is one of the factors that influence satisfaction where men tend to be more satisfied than women who see more in detail. ${ }^{10}$

\section{Description of Respondents by Age}

From the results of the study, it is found that most patients in Yogyakarta Respira Hospital who aresatisfied are those patients of 60 years old of age and older. Gunarsa reveals that as a person's age increases, it can affect his health, where there is a decline in the structure and function of organs, therefore older people tend to use health services more frequently than younger people. ${ }^{11}$ For example, elderly patients who experience musculoskeletal disorders will experience a decline in their function in bone recovery. This can lead to prolonged limitations, hence it can increase their dependence on others. Furthermore, because of 
emotional influence, some of the older people with chronic diseases are more quickly to accept the state of physical limitations than younger people. This is because older people are generally more open, thus elderly patients have lower demand and expectations than younger patients. This causes elderly patients to be more satisfied than younger patients.

From the results of the study, it is found that the satisfaction level was mostly dominated by respondents having a high school education level, meaning that respondents are mostly educated. According to Lumenta, in terms of education, a person with higher education level tends to have higher demand than someone with lower education. $^{12}$ Also, in terms of work, someone who works tends to be more demanding or criticizing the service he receives if he feels dissatisfied with the service compared to those people who do not work.

The research conducted by Wike Diah finds that a person's level of education will have some influence in giving a more rational response to the information that comes and will think how far the benefits might be derived from the idea. In this case the higher one's education, the more opportunity he gets to obtain information and knowledge, where through the length of education pursued through the school level, ${ }^{13}$ the respondent in this case the patient will also get information from various sources.

\section{Description of Respondents by Job}

While having and not having a jobmake no difference, the way they seek information can be different. In reality, when the job earns them lower income, a greater portion of it is used to meet the needs of the family, rather than looking for important information about the disease they experience. This is confirmed by Green's theory, where knowledge has a direct effect on one's specific attitudes and behavior. Job and income characteristics have significant influence on patient characteristics. A person's work can affect their lifestyle and the amount of income used to meet their needs.

\section{Description of Respondents by Sources of Financing to Get Health Services}

From the results of the study, it is found that the satisfied patients mostly use JAMKESMAS/Poor card. This is different from the research conducted by Widia Susanti who finds that Non-Askes patients or general patients are more satisfied with the health services they receive as compared to Askes patients. Average public patients feel more satisfied. This is probably due to the differences in administrative procedures that must be taken by Askes patients. $^{14}$

In accordance with the Government Regulation Year 1991, to obtain services at a hospital, Askes participants must carry out the administrative predetermined procedures. Non-Askes patients, on the other hand, can immediately get services in the hospital without complicated administrative procedures. They can use direct method of payment, i.e. directly paying to health care providers in hospitals, health care centers and private practices. ${ }^{15}$ The differences in administrative procedures can cause lower satisfaction with administrative services in Askes patients compared to non-Askes patients or general patients who pay directly.

From the results of the study, it is found that most patients are treated in the hospital for 4-7 days. The duration of treatment is based not only on the type of disease, rather also on other factors. Patients with the same type of disease are very likely to have a different length of treatment. It is affected emotionally, i.e. how the patient's self-acceptance of the disease. In Anjaryani's research, it is stated that the length of time during which a patient is treated is seen from 2 approaches, either the patient has suffered from the disease for a long time (could be more than a week) or the patients feel at home in the treatment. This arises because things are psychological and administrative as the patient expects them to be.

\section{Input}

Human Resources (HR)

\section{Role of Professional Service Quality}

In fulfilling patient satisfaction, Respira Yogyakarta Hospital has a quality service team for health, i.e. PMKP (Quality Improvement and Patient Safety).

\section{Number of patients}

In terms of the average number of patients, each month the inpatient installations treat more than 45 patients

\section{Process}

Based on the results of interviews with all respondents, there are several obstacles in patient satisfaction as in the table below:

Axial Coding Theme 
1. Patient satisfaction surveys are not conducted regularly

2. Not all understand the indicators of good service quality

3. RS policy is sometimes not appropriate

4. Doctors do not provide the opportunity for patients to ask questions

5. The doctor does not explain the diagnosis to the patient

Theme

Non-routine satisfaction surveys

1. Uneven knowledge

2. Lack of application of SOP

3. Lack of ownership

4. Lack of professionalism Attitude:

1. There are still some content of patient dissatisfaction with the hospital

2. The doctor's attitude is not good in the delivery

3. Complaints related to services provided by the hospital

4. There are several service units that provide complaint facilities but some do not.

\section{Output}

From the research which has been conducted, to determine the level of satisfaction in patients with the special pulmonary Respira Hospital, Yogyakarta, the results obtained indicate that the tangibility dimension has the highest patient satisfaction. There is a percentage of medical equipment at $90 \%$. And the lowest satisfaction level is in the availability of Trolley, with the percentage being $53.33 \%$.

Service quality can be felt directly on the appearance of physical facilities and supporting supporters in the service. From the results of the research on the dimensions of tangibility the level of satisfaction in room cleanliness has a percentage of satisfaction at $73 \%$ satisfied. This means it is good. Then, the level of satisfaction in the comfort of the room is also good, because the percentage of satisfaction is $77 \%$. Moreover, the level of satisfaction in medical equipment is very good with a percentage of satisfaction equal to $90 \%$. Furthermore, the level of satisfaction in the appearance of the physicians is very good, i.e. $83 \%$ satisfied. Next is the level of satisfaction in the appearance of nurses which is very good at a percentage of $80 \%$ satisfied. Then, the level of satisfaction in the availability of Trolleys has a percentage of $53 \%$ satisfied.
Furthermore, the level of satisfaction in the cleanliness of the bed has a percentage of $67 \%$ satisfied. Lastly, $70 \%$ is the percentage in eating tool cleanliness.

From the results of the research above, it can be concluded that the tangibility dimension of patient satisfaction is very good. From the results of the study, it is important to note that the dimensions of Tangiblity factor of patient satisfaction tends to be greater than the dissatisfaction factors, meaning that physical evidence (Tangibility) affects patient satisfaction. This is supported by research conducted by Calisir et al on the effect of quality dimensions on patient satisfaction and repeated visits to 292 respondents using the modified SERVQUAL method which finds that physical evidence is an important factor for patient satisfaction and had an effect on the decision to return to the hospital service. ${ }^{17}$ However, it is in contrast to Supartiningsih's study which states that tangibles do not have positive influence on Sarila Husada Sragen hospital's outpatient patient satisfaction. This can be interpreted that even if the equipment and infrastructure facilities are better, Sarila Husada Sragen hospital patient satisfaction in outpatient care will not be necessarily high.

In the Responsiveness dimension the highest level of satisfaction is dominated by friendly nurses at $76.67 \%$ of the patients being satisfied, and the lowest satisfaction is in the doctor explains the diagnosis item which has a percentage of $30 \%$

From the results of research above, it can be concluded that the tangibility dimensions of patient satisfaction are very good. From the results of the study, it is important to note that the Tangiblity factors of patient satisfaction tend to be greater than the dissatisfaction factors, meaning that physical evidence (Tangibility) affects patient satisfaction, this is supported by the research conducted by Calisir et al on the effect of quality dimensions on satisfaction patients and repeated visits to 292 respondents using the modified SERVQUAL method which finds that physical evidence is an important factor for patient satisfaction and has an effect on the decision to return to the hospital service. However, this is in contrast to Supartiningsih's study who states that tangibles do not have positive influence on Sarila Husada Sragen hospital patient satisfaction on outpatient patients. This can be interpreted that even if the equipment and infrastructure facilities are better, Sarila Husada Sragen hospital patient satisfaction in outpatient care will not necessarily increase altogether. ${ }^{18}$ The research conducted by Syaifullah finds that a good queuing system should reduce direct costs in the form of providing service facilities and indirect costs that 
arise because individuals must wait to be served. If the service facility exceeds the optimal amount, this means that it requires a large investment, but on the contrary, if the amount of costs is non-optimal, the result is a service delay. In implementing the queuing system, hospital management must also consider several factors such as number of employees, costs incurred, time needed in service and provision of supporting facilities in the effective operation to provide optimal services. In addition, service facilities can also support the hospital in working properly and optimally in providing services to patients in checking their health. ${ }^{19}$

Furthermore, the level of satisfaction on the administrative staff's response is $43.33 \%$ satisfied and $56.67 \%$ dissatisfied. Furthermore, the level of satisfaction when the doctor asks the patient for complaints has a percentage of $33.33 \%$ satisfied, and $66.67 \%$ dissatisfied. Staff responsiveness relates to aspects of alertness of officers in meeting patients' needs for services that are desired. The level of alertness of the administrative officers in providing services to patients is one aspect that can affect the patient's assessment of the quality of services provided by the Hospital.

The level of satisfaction in the "doctor gives the patient an opportunity to ask" item has a percentage of $30 \%$ satisfied, $60 \%$ dissatisfied. This level of dissatisfaction is much greater because the doctor does not provide the patient an opportunity to ask, even though the doctor's communication with the patient is an important foundation in the process of diagnosis, therapy and prevention of disease.

Furthermore, the level of satisfaction in the "doctor explains the diagnosis to the patient" item has a percentage of $30 \%$ satisfied, $70 \%$ dissatisfied. This means the level of patient dissatisfaction is much greater than the percentage of satisfaction for such reason as the patient not getting an explanation of the diagnosis of the disease from the doctor. The research conducted by Aulia et al finds that the results of the relationship test indicate that there is no relationship between diagnosis of disease and level of satisfaction. ${ }^{20}$ Generally, when patients come and have been suffering from illness, they want to quickly recover. In addition, sick patients tend to want greater attention. According to the findings in the field, there are not many complaints from health workers.

In the empathy dimension, the satisfaction level is dominated by the "health-friendly attitude" with a percentage reaching $83.33 \%$. Meanwhile, the lowest is the availability of the present consultation time at $33.33 \%$.
From the results of the study, it is found that in the Empathy dimension the level of satisfaction in the healthfriendly attitude has a percentage of $83.33 \%$ satisfied, $16.67 \%$ dissatisfied. Meanwhile, the level of satisfaction in fairness to all patients has a percentage of $76.67 \%$ satisfied, $23.33 \%$ dissatisfied. Furthermore, the level of satisfaction in "nurses always greet" has a percentage of $80 \%$ satisfied, $20 \%$ dissatisfied. Moreover, the level of satisfaction in the "language that is easily understood" item is $63.33 \%$ satisfied, $36.67 \%$ dissatisfied. And the level of satisfaction in gratitude has a percentage of $80 \%$ satisfied, $20 \%$ dissatisfied. The level of satisfaction in the "calming the patient's anxiety" item is $66.67 \%$ satisfied, $33.33 \%$ dissatisfied. Then, the level of satisfaction in the "availability of the consultation time" item is $33.33 \%$ satisfied, $66.67 \%$ dissatisfied. Meanwhile, the level of satisfaction in "entertaining patients" item has a percentage of $66.67 \%$ satisfied, $33.33 \%$ dissatisfied. From the results of the research above, it can be concluded that in the empathy dimension the level of patient satisfaction is good.

Empathy is related to the care and attention of officers to each customer by listening to complaints and understanding the needs and providing convenience for all customers in contacting officers. The research conducted by Al Khattab et al in a study of the quality of health services that compares private and public hospitals in Jordan to 221 respondents find that the main complaint of service in government hospitals is responsiveness and empathy related to service delays and short time consultation. ${ }^{21}$ These shortcomings are the main reason for the lack of perception about the quality of service in government hospitals. The empathy dimension affects patient satisfaction. This is supported by the research of Embrik et al who said that their study provides concrete evidence that the services provided by RSGM UMY in the empathy dimension significantly increase patient satisfaction in using health services. This shows that RSGM UMY can give attention and fully understand the needs of their patients and provide convenience to customers in contacting and communicating with medical personnel and other employees, resulting in satisfaction in the eyes of customers. ${ }^{22}$

In the dimensions of Reliability the highest level of patient satisfaction is in "the coordination between nurses and doctors" item at a percentage of $73.33 \%$ while the lowest is in the "doctor has the time" item at $36.67 \%$.

Reliability is the ability to provide services on time and accurately in accordance with the set standards. In the Dimensions of Reliability the level of satisfaction with "fast 
in the acceptance of patients" item has a percentage of 70\% satisfied, $30 \%$ dissatisfied. Then, the level of satisfaction to the doctor punctuality is $36.67 \%$ satisfied, $63.33 \%$ dissatisfied. Furthermore, the level of satisfaction in the readiness of the doctor has a percentage of $50 \%$ satisfied, $50 \%$ dissatisfied. Then the satisfaction rate of the doctor's rapid action is $53.33 \%$ satisfied, $46.67 \%$ less satisfied. Then, the level of satisfaction with the nurse's readiness is $70 \%$ satisfied, $30 \%$ less satisfied. Then, the level of satisfaction with the coordination between nurses and doctors is $73.33 \%$ satisfied, $26.67 \%$ less satisfied. Next is the level of satisfaction in the procedure of drug administration which has a percentage of $56.67 \%$ satisfied, $43.33 \%$ less satisfied. From the results of the research above, it can be concluded that in the dimensions of Reliability the level of patient satisfaction is good. The reliability factor according to Sangadji is the ability of service providers to provide services quickly, precisely, accurately and satisfactorily. ${ }^{23}$ Whereas according to Muninanjaya the reliability of service providers has something to do with the suitability of services with plans, reliability in delivering initial services, timeliness in providing services, and accuracy of handling. ${ }^{24}$

From the results of the study, it is found that in the Assurance dimensions the percentage of satisfaction level is the greatest, namely the confidentiality of patients with a percentage of $80 \%$, while the lowest percentage is found in the performance of doctors, where the percentage reaches $63.33 \%$.

This dimension is related to the sense of security and comfort of the patient because of the trust in the officers who have the right competence, credibility and skills in providing services and patients obtain a guarantee of safe and comfortable services. From the results of the study, it is found that in the Assurance dimension the percentage of satisfaction level is the greatest, namely the confidentiality of patients with a percentage of $80 \%$, while the percentage level of dissatisfaction is found in the performance of doctors, where the percentage reaches $63.33 \%$. From the results of the research above, it can be concluded that in the Assurance dimension the level of patient satisfaction is good. Each patient basically wants to be treated well by the hospital manager. There is a guarantee that patients who come will be well served by the hospital manager, and the hospital will provide a sense of security to the patient, so that the patient's personal stability will increase. In turn, their trust in the hospital will increase. The relationship of assurance to patient satisfaction is a guarantee of having a positive and significant influence on patient satisfaction.
The better the patient's perception of collateral, the higher the patient's satisfaction will be, and if the patient's perception of collateral is poor then patient satisfaction will be lower. The research on patient satisfaction in Jombang Hospital by Ariyan also finds that a good guarantee will increase patient satisfaction with hospital services, thus making patients tend to believe and be sure of every service performed by the hospital.

This is also supported by the research of Embrik et al who suggest that assurance regarding the friendliness of officers such as being easy smile and being polite has some impact. This is because this friendliness will allow those customers with some bond with the hosptial to tell others and directly become customers in the provision of health services. The results of calculations using cross-tabulation show that $47 \%$ of the patients state that they are very satisfied and $51 \%$ of the patients expressed satisfaction with the assurance they feel at RSGM UMY. Therefore, this is indirectly correlated, even though this dimension is the last factor that can increase perceptions of satisfaction with the quality of service of RSGM UMY. In the dimension of assurance, RSGM UMY has been able to seek aspects of patient comfort, where the RSGM UMY in providing its services always applies hospitality, politeness, and skills to users of health services, so that customer satisfaction arises. The factor analysis shows that this assurance dimension is the last factor of the five factors used as a benchmark in assessing the perception of patient satisfaction on the quality of service at RSGM UMY. Supartiningsih examines the effect of service quality in terms of the dimensions of physical appearance, reliability, responsiveness, assurance, and empathy for the satisfaction of Sarila Husada Sragen hospital patients. Her study finds that assurance affects the satisfaction of patients in Sarila Husada Sragen hospital.

\section{CONCLUSIONS}

From the results and discussion above, some conclusions can be drawn. From the input aspect perspective, (a) the inpatients in Respira Yogyakarta Hospital are satisfied, (b) Respira Yogyakarta Hospital plays a role in the quality of health services, (c) the number of equipment in Yogyakarta Inpatient Installation has met the needs of patients, both in terms of its quality and quantity. Meanwhile, from the process aspect perspective, it can be concluded that: (a) the development of patient satisfaction has involved the health service quality team, (b) some obstacles are still in the way in fulfilling patient satisfaction including non-routine satisfaction surveys, 
uneven knowledge, lack of ownership, lack of professionalism, and (c) the evaluation of patient satisfaction is not done routinely. Finally, from the output aspect perspective, it can be concluded that the patients are satisfied with the service at Respira Yogyakarta Hospital.

\section{REFERENCE}

1. Hafizurrachman, 2004. Multidisciplinary and Multinational Perspectives Service Quality, Lexington Books.

2. Yuwono. 2003. Factors that allow dental caries to occur Semarang State 15 High School. Jakarta: EGC.

3. Yamit, Z. 2002. Quality Management of Products and Services. First Edition. Yogyakarta: Ekonisia UII Faculty of Economics Campus.

4. Wijono. 2008. Hospital Quality Management and Patient Satisfaction Principles and Practices. Surabaya: CV Duta Prima Airlangga. Use Theorema Bayes ". Essay. Yogyakarta: Faculty of Science and Technology. Sunan Kalijaga State Islamic University.

5. Wahyuni D. Relationship between Service Quality and Satisfaction of Outpatients in Puskesmas Tepus 1 Gunung Kidul District Thesis. Ahmad Dahlan University;

6. Price, Sylvia A, 2008. Pathophysiology of the Clinical Concept of Disease Processes 6. EGC Medical Book Publishers.

7. Pohan, 2003. Quality Assurance of Health Services. Kesaint Blane: Bekasi

8. Muninjaya, A.A. Gde. (2004) Health Management. Jakarta: EGC Medicine Book.

9. Supranto, J. 2000. Theory Statistic and aplication. Jilid 1 Edision 6. Erlanggga: Jakarta.

10. Gunarsa, Singgih. 2008. Care Psychology. Jakarta: Gunung Mulia

11. Trisnantoro, L., 2004. Changes in the Management System and Excellent Services, Workshop on the Use of Economic Pharmaco Concepts for Excellent Services in the Drug Sector. Gadjah Mada University. Yogyakarta

12. Gunarsa, Singgih. 2008. Care Psychology. Jakarta: Gunung Mulia

13. Lumenta, Benjamin 1989. Patient, Image, Role and Behavior, Review of Social Phenomena. Kanisius, Yogyakarta

14. Wike Diah, 2009 Patient Satisfaction Inpatient Services Nurse at Tugurejo Hospital Semarang
15. Widia Susanti, 2008, Financing system and other influencing factors patient satisfaction in dental and oral health services at DR. Moewardi Surakarta

16. Azwar 1998. Introduction to Administration, Second Edition, Aksara Binarupa Publisher, Jakarta

17. Anjaryani, WD. 2009. Patient Satisfaction Inpatient Services Nurse at Tugurejo Hospital Semarang

18. Calisir, F., C.A. Gumussoy, A.E. Bayraktaroglu and B. Kaya. 2012. Effects of Service Quality Dimensions on Customer Satisfaction and Return Intention in Different Hospital Types. Proceedings of the 2012 International Conference on Industrial Engineering and Operations Management, pp. 518 522

19. Solichah Supartiningsih, 2017, Journal of Medicoeticolegal and Hospital Management, Vol 6 No. 1, Quality of Service and Hospital Patient Satisfaction Cases in Outpatients

20. Syaifullah, 2010, The Analysis System Queue to Increase Efectiveness of Services in Hospitals Islam Ibnu Sina Pekan Baru, Thesis, Riau

21. Aulia Nur Hidayati, 2014, Analysis of the Relationship between Patient Characteristics and Semarang Eye Center (SEC) Outpatient Service Satisfaction in Sultan Agung Semarang Islamic Hospital, JURNAL OF PUBLIC HEALTH Volume 2, Number 1

22. Al Khattab, S. and A.H. Aborumman. 2011. Health Service Quality: Comparing Public and Private Hospitals in Jordan. International Business Management Vol 5 No. 5, pp. 247 - 254

23. Ina Solihati Embrik, et al, 2013, Perception of patient satisfaction in oral and dental health services at Muhammadiyah University of Yogyakarta, JMMR UMY, VOL 2 NO 1

24. Sangadji, E.M., and Sopiah. 2013. Consumer Behavior: Practical Approach Accompanied: Research Journal Association. Yogyakarta: Publisher Andi. 